\title{
Article \\ Effect of Ozonated Fertigation in Pepper Cultivation under Greenhouse Conditions
}

\author{
Julian Colunje ${ }^{1}(\mathbb{D})$, Pedro Garcia-Caparros ${ }^{1}$, Jorge F. Moreira ${ }^{1,2}$ and María Teresa Lao ${ }^{1, * \mathbb{D}}$ \\ 1 Department of Agronomy, University of Almeria, 04120 Almeria, Spain; juliancolunje@hotmail.com (J.C.); \\ pedrogar123@hotmail.com (P.G.-C.); jorge.moreira@cu.ucsg.edu.ec (J.F.M.) \\ 2 Faculty of Technical Education for Development, Catholic University of Santiago of Guayaquil, \\ 09014671 Guayaquil, Ecuador \\ * Correspondence: mtlao@ual.es
}

Citation: Colunje, J.;

Garcia-Caparros, P.; Moreira, J.F.; Lao, M.T. Effect of Ozonated Fertigation in Pepper Cultivation under Greenhouse Conditions. Agronomy 2021, 11, 544. https://doi.org/ 10.3390/agronomy11030544

Academic Editors: Giuseppe Colla and Byoung Ryong Jeong

Received: 27 January 2021

Accepted: 10 March 2021

Published: 13 March 2021

Publisher's Note: MDPI stays neutral with regard to jurisdictional claims in published maps and institutional affiliations.

Copyright: (C) 2021 by the authors. Licensee MDPI, Basel, Switzerland. This article is an open access article distributed under the terms and conditions of the Creative Commons Attribution (CC BY) license (https:// creativecommons.org/licenses/by/ $4.0 /)$.

\begin{abstract}
Ozone has a high oxidizing power avoiding the presence of residues, so it is a good candidate for use in organic farming. However, its application in fertigation has been little studied. Two experiments were conducted simultaneously to check the aims of this work. The aim of the first experiment was to study pepper response under the nutrient solution supply and the application of $\mathrm{O}_{3}$ and its interactions, and the aim of the second experiment was to determine the optimal dosage of $\mathrm{O}_{3}$ to be supplied, from the point of view of plant development and nutritional and physiological status in both experiments. We conclude that $\mathrm{O}_{3}$ supply via fertigation increased pepper biomass production. According to the results obtained, we recommend that the optimal dosage of $\mathrm{O}_{3}$ in pepper plants be from 0.18 to $0.36 \mathrm{mg} \mathrm{L}^{-1}$ due to its higher associated biomass production. Under these dosages, pepper plants showed a higher leaf area and higher photosynthetic pigment concentration. Similarly, under these dosages, N, P, and K plant uptake were higher, allowing a higher synthesis of bioassimilates.
\end{abstract}

Keywords: biomass; chlorophyll; nitrogen; phosphorus; potassium; proline; sugars

\section{Introduction}

The current demand for quality horticultural products considering the international standards of safety, good agricultural practices (GAP), and sustainable development has led to the development of practices such as organic fertilization, the rational use of water and nutrients, and the biological control of pests and diseases, among others. With respect to the rational use of water and nutrients, different technologies have been studied such as sub-irrigated planter systems [1], recirculation in hydroponic systems [2], and the implementation of cascade cropping systems [3,4]. Nevertheless, the reuse of the leachate increases the risk of pathogens such as Verticillium dahliae and Phytophthora capsici [5], which are disseminated by water [6].

Disinfection strategies for soils, substrates, and irrigation water include the use of different chemical compounds such as methyl bromide, chloropicrin, dazomet, and metam sodium, which are currently banned in the European Union [7]. Nowadays, the agricultural implementation of sustainable alternatives for cleaning urban wastewater through oxidative degradation of organic matter are based on the application of other chemical compounds with lower toxicity, such as hydrogen peroxide $\left(\mathrm{H}_{2} \mathrm{O}_{2}\right)$ [8], chlorine $\left(\mathrm{Cl}_{2}\right)$, peroxyacetic acid $\left(\mathrm{C}_{2} \mathrm{H}_{4} \mathrm{O}_{3}\right)$ [9,10], and ozone $\left(\mathrm{O}_{3}\right)$ [11], the most recently implemented.

Ozone has a higher oxidizing power than $\mathrm{H}_{2} \mathrm{O}_{2}, \mathrm{Cl}_{2}$, or $\mathrm{C}_{2} \mathrm{H}_{4} \mathrm{O}_{3}$. The molecule of $\mathrm{O}_{3}$ is unstable; it decomposes into hydroxyl radicals $\left(\mathrm{OH}^{-}\right)$, hydroperoxide $\left(\mathrm{HO}_{2}^{-}\right)$, and superoxide $\left(\mathrm{O}_{2}{ }^{-}\right)$, which are responsible for microbial inactivation through a process of the cytoplasmic membrane and cell-wall destruction [12]. These properties confer to this compound a high bactericidal, virucidal, and fungicidal effect. Therefore, $\mathrm{O}_{3}$ is considered the fastest method for inactivation or elimination compared to other disinfecting agents 
that require penetration of the cell membrane to be effective. Consequently, $\mathrm{O}_{3}$ is also used in other fields such as industrial and medical processes, for instance, disinfection of COVID-19 material [13]. Nevertheless, it is necessary to highlight its toxicity. The European Commission established that the human exposure hazard to $\mathrm{O}_{3}$ is $120 \mu \mathrm{g} \mathrm{m}^{-3}$ with a maximum daily exposure of $8 \mathrm{~h}$ (Directive 2008/50/CE) [14].

Regarding the effects of high concentrations of tropospheric $\mathrm{O}_{3}$ on different crops, there are several references in the literature. For instance, Macdowall et al. [15] reported the presence of necrosis in tobacco leaves (weather fleck) in environments with up to $40 \mathrm{ppb}$ of $\mathrm{O}_{3}$ gas during 14 continuous hours at night. Likewise, Kumari et al. [16] reported a growth reduction in Beta vulgaris under a concentration of $70 \mathrm{ppb}$ of $\mathrm{O}_{3}$. Nevertheless, the experiments carried out with dissolved $\mathrm{O}_{3}$ in irrigation water are scarce. For instance, Graham et al. [17], Graham et al. [18], and Martínez-Sánchez and Aguayo [19] reported the positive effect of the application of dissolved $\mathrm{O}_{3}$ in irrigation water in five nursery crops, in tomato, and in pepper, respectively. Therefore, we aimed to check whether this positive effect occurs with dissolved $\mathrm{O}_{3}$ in pepper crops in two different scenarios: under irrigation with water or fertigation with a standard nutrient solution, and also to determine the optimal concentration of $\mathrm{O}_{3}$ supply by focusing on the changes caused at the physiological and nutritional level in pepper plants.

\section{Materials and Methods}

\subsection{Location and Facilities}

The experiments were conducted in a mono-tunnel greenhouse at the University of Almería $\left(36^{\circ} 49^{\prime} \mathrm{N}, 2^{\circ} 24^{\prime} \mathrm{W}\right)$. The greenhouse was covered by polycarbonate stratified with transparent fiberglass together with a white mesh of $25 \%$ shading. Weather conditions inside the greenhouse were recorded with HOBO SHUTTLE sensors (model U12-13, Onset Computer Corp., Bourne, MA, USA). The average values of temperature, relative humidity, and photosynthetically active radiation (PAR) recorded during the experimental period were $27.05 \pm 1.4{ }^{\circ} \mathrm{C}, 62.89 \pm 2.4 \%$, and $16.62 \pm 1.3 \mathrm{MJ} \mathrm{m}^{-2}$ day $^{-1}$, respectively. The cultivation was carried out on metal tables with a surface of $12 \mathrm{~m}^{2}$ and a height of $80 \mathrm{~cm}$.

\subsection{Plant Material}

Capsicum annum $\mathrm{L}$. var. Claque $\mathrm{F}_{1}$ (Rijk Zwaan) seedlings were purchased from a commercial nursery and then transplanted into $4 \mathrm{~L}$ plastic containers filled with blond peat moss. Under each pot, plastic buckets were used to collect generated leachate. The experiment lasted for 50 days (from 26 April to 15 July, 2019). The planting density was 2 plants $\mathrm{m}^{-2}$.

\subsection{Experimental Design and Treatments}

Two experiments were conducted simultaneously with pepper plants. The first experiment was carried out to check whether there were differences in physiological and nutritional properties in pepper plants irrigated with water or nutrient solution with or without $\mathrm{O}_{3}$. The experimental design was a bifactorial split-plot (fertigation or not and supplies of $\mathrm{O}_{3}$ or not) completely randomized with four blocks and four plants (pots) per treatment combination block in each treatment. The second experiment was carried out to test the effect of increasing $\mathrm{O}_{3}$ concentrations in the nutrient solution on pepper plants at the physiological and nutritional levels. The experimental design was composed of four levels of $\mathrm{O}_{3}$ concentration, four blocks, and four plants (pots) per block (Table 1). The chemical composition of irrigation water and nutrient solution is shown in Table 2. The nutrient solution used was the same supplied by local growers of this crop and was achieved with irrigation water and added simple fertilizers. 
Table 1. Characterization of fertigation treatments. Irrigation water $\left(\mathrm{NS}_{0}\right)$ and fertigation with the standard nutrient solution $\left(\mathrm{NS}_{1}\right) ; \mathrm{O}_{0}, 0.18,0.36,0.54$ : ozone at different concentrations $(0,0.18,0.36$, and $0.54 \mathrm{mg} \mathrm{L}^{-1}$, respectively).

\begin{tabular}{ccc}
\hline & Fertigation & O $_{3}$ Supply \\
\hline Experiment 1 & $\mathrm{NS}_{0}$ & $\mathrm{O}_{0}$ \\
\hline & $\mathrm{NS}_{0}$ & $\mathrm{O}_{0.54}$ \\
\hline & $\mathrm{NS}_{1}$ & $\mathrm{O}_{0}$ \\
\hline Experiment 2 & $\mathrm{NS}_{1}$ & $\mathrm{O}_{0.54}$ \\
\hline & $\mathrm{NS}_{1}$ & $\mathrm{O}_{0}$ \\
\hline & $\mathrm{NS}_{1}$ & $\mathrm{O}_{0.18}$ \\
\hline & $\mathrm{NS}_{1}$ & $\mathrm{O}_{0.36}$ \\
\hline & $\mathrm{NS}_{1}$ & $\mathrm{O}_{0.54}$ \\
\hline
\end{tabular}

Table 2. Chemical characterization of the tap water and the standard nutrient solution (NS). Electrical conductivity (EC) and macronutrient concentration are expressed in $\mathrm{dS} \mathrm{m}^{-1}$ and $\mathrm{mmol} \mathrm{L}^{-1}$, respectively.

\begin{tabular}{ccccccccccc}
\hline & $\mathbf{E C}$ & $\mathbf{p H}$ & $\mathbf{N O}_{3}{ }^{-}$ & $\mathbf{H}_{\mathbf{2}} \mathbf{P O}_{4}{ }^{2-}$ & $\mathbf{S O}_{4}{ }^{2-}$ & $\mathbf{C l}^{-}$ & $\mathbf{K}^{+}$ & $\mathbf{C a}^{2+}$ & $\mathbf{M g}^{2+}$ & $\mathbf{N a}^{+}$ \\
\hline Water & 0.9 & 8.1 & 0 & 0 & 1.1 & 3.5 & 0 & 2 & 1.4 & 2.6 \\
NS & 1.3 & 6 & 6 & 0.7 & 1.1 & 3.5 & 3 & 2 & 1.4 & 2.6 \\
\hline
\end{tabular}

To generate $\mathrm{O}_{3}$ for its application in the fertigation system, the Evozon3 system (Evo Industria, Malaga, Spain) was used. This system is based on the capture of ambient air through a centrifugal pump ( $3 \mathrm{~kg} \mathrm{~cm}^{-2}$ of pressure and $3.5 \mathrm{~m}^{3} \mathrm{~h}^{-1}$ of flow rate), where $\mathrm{O}_{2}$ is filtered with zeolite and sent to a concentrator at a flow of $8 \mathrm{~L} \mathrm{~min}^{-1}$ to reduce the humidity to $14 \%$. Then $\mathrm{O}_{2}$ is ionized with a high voltage current of $9000 \mathrm{~V}$, releasing one of the atoms of oxygen and causing the binding of this atom with another $\mathrm{O}_{2}$ molecule, resulting in $\mathrm{O}_{3}$ molecules. The $\mathrm{O}_{3}$ produced with a concentration of $10 \mathrm{~g} \mathrm{~h}^{-1}$ is then injected by a submersible Venturi system and a flash reactor, which favors its mixing and homogeneity in a $120 \mathrm{~L}$ water tank from the network.

The equipment also has a $\mathrm{pH}$ and oxidation-reduction potential $(\mathrm{mV})$ probe (PHTK160 Digital PH ORP (2 in 1), Teckoplus Ltd., Trademart Dr, Kowloon Bay, Hong Kong). The system works for $30 \mathrm{~min}$, reaching around 850 to $1000 \mathrm{mV}$, and after this period the ozonated water had the optimum conditions for its use in the experiments. There is a table conversion between power redox and $\mathrm{O}_{3}$ concentration to check continuously that the optimal conditions of the experiment were being conducted, following the recommendations given by TopOzono [20] and the advice given by local growers (Table 3).

Table 3. Conversion between power redox $(\mathrm{mV})$ and $\mathrm{O}_{3}$ concentration $\left(\mathrm{mg} \mathrm{L}^{-1}\right)$.

\begin{tabular}{cc}
\hline Power Redox $(\mathbf{m V})$ & $\mathbf{O}_{3}$ Concentration \\
\hline 0 & 0 \\
225 & 0.18 \\
450 & 0.36 \\
675 & 0.54 \\
\hline
\end{tabular}

A standard nutrient solution was then prepared and concentrated 4 times. The design of the ozonated treatments as well as the levels in $\mathrm{mg} \mathrm{L}^{-1}$ of $\mathrm{O}_{3}$ or $\mathrm{mV}$ of the oxidationreduction potential are shown in Table 4. 
Table 4. Description of the mixing percentage in the different experimental treatments. Irrigation water $\left(\mathrm{NS}_{0}\right)$ and fertigation with the standard nutrient solution $\left(\mathrm{NS}_{1}\right) ; \mathrm{O}_{0}, 0.18,0.36,0.54$ : ozone at different concentrations $\left(0,0.18,0.36\right.$, and $0.54 \mathrm{mg} \mathrm{L}^{-1}$, respectively).

\begin{tabular}{ccccc}
\hline & \multicolumn{4}{c}{ Mixing Percentage (\%) } \\
\hline & Treatments & $\begin{array}{c}\text { Nutrient } \\
\text { Solution }\end{array}$ & $\begin{array}{c}\text { Ozonated Water } \mathbf{0 . 8} \\
\left.\mathbf{m g ~ L}^{-\mathbf{1}} \mathbf{(} \pm \mathbf{9 0 0} \mathbf{~ m V}\right)\end{array}$ & Irrigation Water \\
\hline \multirow{2}{*}{ Experiment 1} & $\mathrm{NS}_{0} \mathrm{O}_{0}$ & 0 & 0 & 100 \\
& $\mathrm{NS}_{0} \mathrm{O}_{0.54}$ & 0 & 75 & 25 \\
& $\mathrm{NS}_{1} \mathrm{O}_{0}$ & 25 & 0 & 75 \\
& $\mathrm{NS}_{1} \mathrm{O}_{0.54}$ & 25 & 75 & 0 \\
& $\mathrm{NS}_{1} \mathrm{O}_{0}$ & 25 & 0 & 75 \\
& $\mathrm{NS}_{1} \mathrm{O}_{0.18}$ & 25 & 25 & 50 \\
& $\mathrm{NS}_{1} \mathrm{O}_{0.36}$ & 25 & 50 & 25 \\
& $\mathrm{NS}_{1} \mathrm{O}_{0.54}$ & 25 & 75 & 0 \\
\hline
\end{tabular}

The irrigation was performed manually using graduated cylinders. Although the volume of irrigation was $200 \mathrm{~mL}$ per plant day ${ }^{-1}$, the frequency of irrigation was adjusted weekly in order to achieve a drainage percentage of around $30 \%$.

\subsection{Biometric Parameters}

At the end of the experimental period, four plants per block and treatment were randomly selected and the substrate was gently removed with distilled water, avoiding the loss of roots. Each plant was divided into roots, stem, leaves, and fruits and then those organs were washed and dried with blotting paper to be weighed (fresh weight, FW) and then oven dried at $60^{\circ} \mathrm{C}$ for $48 \mathrm{~h}$ for the determination of the dry weight (DW). These dry weights were used to determine several plant parameters, such as relative root weight ratio (RWR; root DW per unit plant DW), stem weight ratio (SWR; stem DW per unit plant DW), leaf weight ratio (LWR; leaf DW per unit plant DW), and fruit weight ratio (FWR; fruit DW per unit plant DW) as described by Garcia-Caparros et al. [21]. The total plant dry weight (TDW) was calculated as the DW sum of the roots, stems, leaves, and fruits. The fresh and dry weight of the total plant were used to calculate the relative plant water content (RWC) as indicated by Ben Amor et al. [22]. The total leaf area was determined by digitalized images of each plant using the Idrisi Selva computer program (Clark Laboratories, Worcester, MA, USA), as reported by Garcia-Caparros et al. [23].

\subsection{Physiological Parameters}

At the end of the experimental period, four plants were randomly selected per block and treatment for the determination of pigment concentrations. Fresh samples of leaves $(0.2 \mathrm{~g})$ were submerged in methanol for $24 \mathrm{~h}$ under dark conditions at room temperature (RT). The supernatant was removed, and the pigment concentrations were recorded spectrophotometrically using the following equations reported by Wellburn [24]. Pigment concentrations were expressed in $\mathrm{mg} \mathrm{g}^{-1} \mathrm{FW}$.

$$
\begin{aligned}
& \text { Chlorophyll } \mathrm{a}=([(15.65 \times \text { A_666 })-(7.34 \times \text { A_653 })] \times 15) / 2 \\
& \text { Chlorophyll b }=([(27.05 \times \text { A_653 })-(11.21 \times \text { A_666 })] \times 15) / 2
\end{aligned}
$$

where A_653 and A_666 are the absorbance readings at 653 and $666 \mathrm{~nm}$, respectively.

The concentration of total soluble sugars and proline in leaves was determined in four plants randomly selected by treatment, following the methodology proposed by Irigoyen et al. [25]. The total soluble sugars were estimated using the anthrone reagent and the concentration of free proline was analyzed colorimetrically using ninhydrin reagent. The total soluble sugars in leaves were expressed in mg glucose $\mathrm{g}^{-1} \mathrm{FW}$ and leaf proline concentration in $\mu \mathrm{g} \mathrm{g}^{-1} \mathrm{FW}$. 


\subsection{Nutritional Parameters}

The determination of nutrient concentration in the different organs assessed was performed on ground oven-dried samples. The samples were mineralized with $\mathrm{H}_{2} \mathrm{SO}_{4}(96 \%)$ and hydrogen peroxide (P-free) at $300{ }^{\circ} \mathrm{C}$. Nitrogen and $\mathrm{P}$ concentrations in the different organs were analyzed following the protocols of Cataldo et al. [26] and Hogue et al. [27], respectively. The determination of $\mathrm{K}^{+}$concentration was assessed by flame spectrometry [28]. Nutrient concentrations were expressed in $\mathrm{mg} \mathrm{g}^{-1} \mathrm{DW}$. From these determinations and with the DW measured, the plant nutrient content and partitioning in the different organs were calculated. The partitioning in the different organs was calculated by dividing the nutrient extraction of each organ by the total plant nutrient uptake.

\subsection{Statistical Analysis}

The experiment was analyzed as a completely randomized block design; the values obtained for each plant and each variable were considered as independent replicates. Analysis of bifactorial and unifactorial variance (ANOVA) was used and the statistical evaluations of the differences between the means of the treatments were performed by Fisher's least significant difference (LSD) tests at $p<0.05$ using Statgraphics Plus for Windows (Statpoint Technologies Inc., Warrenton, VA, USA).

\section{Results}

\subsection{Biometric Parameters}

During the experimental period, there was neither mortality of plants nor incidence of pests or diseases noted for the treatments assessed. The fertigation with the standard nutrient solution and the application of $\mathrm{O}_{3}$ increased significantly the total dry weight in pepper plants. For the partitioning of biomass, there were different trends among the different organs assessed. Root weight ratio increased under irrigation water and ozone application. Stem and leaf weight ratios increased under fertigation with the nutrient solution, regardless of the ozone application. The absence of nutrient solution caused an acceleration of the plant cycle, showing a higher value in fruit weight ratio $(16 \%)$. Relative water content decreased under fertigation with the nutrient solution, regardless of the ozone application. Leaf area remained unchanged under the different factors assessed (Table 5).

Table 5. Effects of fertigation treatments (FT) and ozone application on C. annuum biometric parameters. Data are the means \pm standard deviation of four samples per treatment. In a column and treatment, the same letter indicates no significant differences among treatments at the $p<0.05$ level by LSD test.

\begin{tabular}{|c|c|c|c|c|c|c|c|c|}
\hline & & TDW & RWR & SWR & LWR & FWR & RWC & LA \\
\hline & & * & * & * & * & * & * & ns \\
\hline Fertigation treatments & $\mathrm{NS}_{0}$ & $5.62 \pm 0.34 b$ & $0.13 \pm 0.003 \mathrm{a}$ & $0.43 \pm 0.03 \mathrm{~b}$ & $0.27 \pm 0.02 \mathrm{~b}$ & $0.16 \pm 0.01 \mathrm{a}$ & $7.68 \pm 0.20 \mathrm{a}$ & $0.25 \pm 0.02$ \\
\hline Ozone & $\mathrm{NS}_{1}$ & $\underset{*}{7.17 \pm 0.46 \mathrm{a}}$ & $0.11 \pm \underset{*}{0.002} \mathrm{~b}$ & $\begin{array}{c}0.53 \pm 0.03 \mathrm{a} \\
\text { ns }\end{array}$ & $\begin{array}{c}0.35 \pm 0.02 \mathrm{a} \\
\mathrm{ns}\end{array}$ & $\begin{array}{c}0.00 \pm 0.00 \mathrm{~b} \\
\mathrm{~ns}\end{array}$ & $\begin{array}{c}7.28 \pm 0.19 b \\
n s\end{array}$ & $\begin{array}{c}0.28 \pm 0.02 \\
\mathrm{~ns}\end{array}$ \\
\hline & $\mathrm{O}_{0}$ & $5.80 \pm 0.35 b$ & $0.11 \pm 0.002 \mathrm{~b}$ & $0.47 \pm 0.04$ & $0.32 \pm 0.02$ & $0.07 \pm 0.01$ & $7.31 \pm 0.20$ & $0.25 \pm 0.02$ \\
\hline Interactions & $\mathrm{O}_{0.54}$ & $\begin{array}{c}6.99 \pm 0.47 \mathrm{a} \\
\mathrm{ns}\end{array}$ & $\begin{array}{c}0.13 \pm 0.003 \mathrm{a} \\
\mathrm{ns}\end{array}$ & $\begin{array}{c}0.49 \pm 0.03 \\
\text { ns }\end{array}$ & $\begin{array}{c}0.30 \pm 0.03 \\
\text { ns }\end{array}$ & $\begin{array}{c}0.09 \pm 0.01 \\
\text { ns }\end{array}$ & $\begin{array}{c}7.56 \pm 0.18 \\
\mathrm{~ns}\end{array}$ & $\begin{array}{c}0.28 \pm 0.02 \\
\mathrm{~ns}\end{array}$ \\
\hline
\end{tabular}

* indicates significant differences among treatments at the $p<0.05$ level by LSD test.

Pepper plants grown under $\mathrm{O}_{0.18}$ and $\mathrm{O}_{0.36}$ treatments showed the highest total dry weight (TDW). For biomass partitioning, there were significant differences between treatments. The addition of $\mathrm{O}_{3}$ at $0.54 \mathrm{mg} \mathrm{L}^{-1}$ significantly decreased the leaf weight ratio (LWR) (Table 6). With $\mathrm{O}_{3}$ application, there was an increase in stem weight ratio (SWR) and a decrease in root weight ratio (RWR). Relative water showed the highest value in pepper plants grown under the highest $\mathrm{O}_{3}$ concentration. Leaf area increased under $\mathrm{O}_{0.18}$ and $\mathrm{O}_{0.36}$ treatments but decreased at $\mathrm{O}_{0.54}$, showing a similar value as the control treatment (Table 6). 
Table 6. Effects of increasing $\mathrm{O}_{3}$ concentration in fertigation with the standard nutrient solution on C. annuum biometric parameters.

\begin{tabular}{ccccccc}
\hline & TDW & LWR & SWR & RWR & RWC & LA \\
\hline $\mathrm{O}_{0}$ & $6.70 \pm 0.13 \mathrm{c}$ & $0.37 \pm 0.01 \mathrm{a}$ & $0.51 \pm 0.005 \mathrm{c}$ & $0.12 \pm 0.005 \mathrm{a}$ & $7.13 \pm 0.10 \mathrm{~b}$ & $0.27 \pm 0.01 \mathrm{c}$ \\
$\mathrm{O}_{0.18}$ & $7.94 \pm 0.14 \mathrm{a}$ & $0.36 \pm 0.01 \mathrm{ab}$ & $0.55 \pm 0.010 \mathrm{a}$ & $0.10 \pm 0.007 \mathrm{~b}$ & $6.28 \pm 0.09 \mathrm{c}$ & $0.31 \pm 0.01 \mathrm{~b}$ \\
$\mathrm{O}_{0.36}$ & $7.87 \pm 0.09 \mathrm{ab}$ & $0.35 \pm 0.01 \mathrm{ab}$ & $0.53 \pm 0.005 \mathrm{~b}$ & $0.10 \pm 0.006 \mathrm{~b}$ & $7.11 \pm 0.10 \mathrm{~b}$ & $0.33 \pm 0.01 \mathrm{a}$ \\
$\mathrm{O}_{0.54}$ & $7.64 \pm 0.13 \mathrm{~b}$ & $0.30 \pm 0.02 \mathrm{~b}$ & $0.53 \pm 0.005 \mathrm{~b}$ & $0.10 \pm 0.007 \mathrm{~b}$ & $7.36 \pm 0.12 \mathrm{a}$ & $0.28 \pm 0.01 \mathrm{c}$ \\
\hline
\end{tabular}

Data are the means \pm standard deviation of four samples per treatment. In a column, the same letter indicates no significant differences among treatments at the $p<0.05$ level by LSD test.

\subsection{Physiological Parameters}

Fertigation with the standard nutrient solution and without the application of $\mathrm{O}_{3}$ increased the pigment concentrations and leaf proline concentrations in pepper plants. Leaf total soluble sugars remained unchanged regardless of the fertigation treatment or ozone application (Table 7). There were statistically significant differences between fertigation treatments and ozone application in pigment concentrations. The application of $\mathrm{O}_{3}$ reduced values in Chl a and $\mathrm{b}$ only in the standard nutrient solution (Figure 1).

Table 7. Effects of fertigation treatments (FT) and ozone application on C. annuum physiological parameters. Data are the means \pm standard deviation of four samples per treatment. In a column and treatment, the same letter indicates no significant differences among treatments at the $p<0.05$ level by LSD test.

\begin{tabular}{|c|c|c|c|c|c|c|}
\hline & & Chl a & Chl b & Chl $a+b$ & TSS & Proline \\
\hline Fertigation treatments & & * & * & * & ns & * \\
\hline & $\mathrm{NS}_{0}$ & $2.58 \pm 0.34 b$ & $1.57 \pm 0.21 b$ & $4.15 \pm 0.31 \mathrm{~b}$ & $43.45 \pm 2.71$ & $52.20 \pm 3.34 \mathrm{~b}$ \\
\hline Ozone & $\mathrm{NS}_{1}$ & $\begin{array}{c}8.15 \pm 0.56 \mathrm{a} \\
*\end{array}$ & $\begin{array}{c}4.36 \pm 0.38 \mathrm{a} \\
*\end{array}$ & $\begin{array}{c}12.51 \pm 0.81 \mathrm{a} \\
*\end{array}$ & $\begin{array}{c}45.26 \pm 2.67 \\
\text { ns }\end{array}$ & $\begin{array}{c}135.73 \pm 8.75 \mathrm{a} \\
*\end{array}$ \\
\hline & $\mathrm{O}_{0}$ & $5.97 \pm 0.45 \mathrm{a}$ & $3.37 \pm 0.24 \mathrm{a}$ & $9.34 \pm 0.73 \mathrm{a}$ & $44.64 \pm 2.27$ & $102.21 \pm 6.57 \mathrm{a}$ \\
\hline Interactions & $\mathrm{O}_{0.54}$ & $\underset{*}{4.76 \pm 0.37 \mathrm{~b}}$ & $\underset{*}{2.57 \pm 0.18 b}$ & $\begin{array}{c}7.33 \pm 0.66 \mathrm{~b} \\
*\end{array}$ & $\begin{array}{c}47.06 \pm 2.90 \\
\text { ns }\end{array}$ & $\begin{array}{c}85.73 \pm 5.71 b \\
n s\end{array}$ \\
\hline
\end{tabular}

${ }^{*}$ indicates significant differences among treatments at the $p<0.05$ level by LSD test.
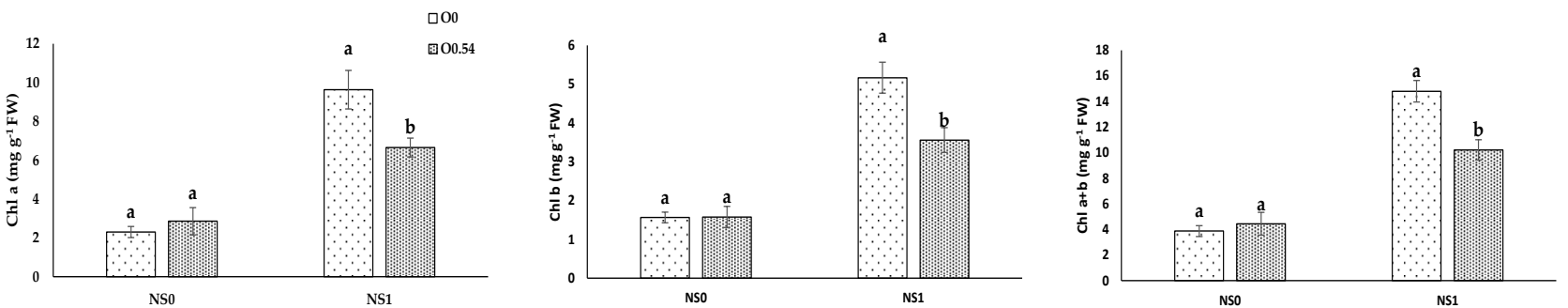

Figure 1. Interactions between fertigation treatments and ozone application on pigment concentrations. The same letter indicates no significant differences among treatments at the $p<0.05$ level by LSD test.

The highest value of total chlorophyll concentration was achieved in pepper plants grown under the $\mathrm{O}_{0.18}$ treatment. There was a pigment concentration decline at higher concentrations of $\mathrm{O}_{3}$. The lowest value of total soluble sugar concentration was for $\mathrm{O}_{0.18}$, whereas for proline concentration this treatment showed the highest value (Table 8). 
Table 8. Effect of increasing $\mathrm{O}_{3}$ concentration in fertigation with the standard nutrient solution on C. annuum physiological parameters

\begin{tabular}{cccccc}
\hline & Chl a & Chl b & Chl $\mathbf{a}+\mathbf{b}$ & TSS & Proline \\
\hline $\mathrm{O}_{0}$ & $9.64 \pm 0.73 \mathrm{a}$ & $5.17 \pm 0.27 \mathrm{~b}$ & $14.81 \pm 0.49 \mathrm{~b}$ & $44.64 \pm 2.56 \mathrm{a}$ & $147.96 \pm 8.24 \mathrm{ab}$ \\
$\mathrm{O}_{0.18}$ & $8.95 \pm 0.79 \mathrm{a}$ & $6.49 \pm 0.37 \mathrm{a}$ & $15.44 \pm 0.57 \mathrm{a}$ & $33.60 \pm 2.14 \mathrm{~b}$ & $154.83 \pm 7.39 \mathrm{a}$ \\
$\mathrm{O}_{0.36}$ & $7.52 \pm 0.62 \mathrm{~b}$ & $5.19 \pm 0.29 \mathrm{~b}$ & $12.71 \pm 0.50 \mathrm{~b}$ & $46.97 \pm 2.89 \mathrm{a}$ & $121.03 \pm 6.34 \mathrm{~b}$ \\
$\mathrm{O}_{0.54}$ & $6.66 \pm 0.35 \mathrm{~b}$ & $3.56 \pm 0.19 \mathrm{c}$ & $10.22 \pm 0.39 \mathrm{c}$ & $47.88 \pm 2.94 \mathrm{a}$ & $123.51 \pm 6.22 \mathrm{~b}$ \\
\hline
\end{tabular}

Data are the means \pm standard deviation of four samples per treatment at the end of the trial. In a column, the same letter indicates no significant differences among treatments at the $p<0.05$ level by LSD test.

\subsection{Nutritional Parameters}

\subsubsection{Nitrogen}

The total nitrogen extracted from plants (TNE) increased under fertigation with the standard nutrient solution and without the application of $\mathrm{O}_{3}$. For the partitioning in the different organs assessed, the root nitrogen ratio (RNR) decreased under fertigation with the standard nutrient solution and the application of $\mathrm{O}_{3}$. The stem nitrogen ratio (SNR) only decreased in pepper plants irrigated with water regardless of the $\mathrm{O}_{3}$ application. The leaf nitrogen ratio (LNR) remained unchanged under the two factors assessed. The fruit nitrogen ratio (FNR) only increased in pepper plants irrigated with water regardless of the $\mathrm{O}_{3}$ application, because under fertigation with the standard nutrient solution, fruits were not developed (Table 9). There were statistically significant differences between the interactions of fertigation treatments and $\mathrm{O}_{3}$ application in the total nitrogen extracted (TNE) from plants. Under water irrigation there was no significant difference between ozone applications (Figure 2).

Table 9. Effects of fertigation treatments (FT) and ozone application on total nitrogen extracted from plants (TNE) (mg plant $^{-1}$ ) and their distribution in root (RNR), stem (SNR), leaf (LNR), and fruit (FNR) in C. annum at the end of the experimental period. Data are the means \pm standard deviation of four samples per treatment. In a column and treatment, the same letter indicates no significant differences among treatments at the $p<0.05$ level by LSD test.

\begin{tabular}{|c|c|c|c|c|c|c|}
\hline & & TNE & RNR & SNR & LNR & FNR \\
\hline FT & & * & * & * & ns & * \\
\hline & $\mathrm{NS}_{0}$ & $49.70 \pm 2.85 b$ & $0.15 \pm 0.01 \mathrm{a}$ & $0.29 \pm 0.02 b$ & $0.39 \pm 0.03$ & $0.16 \pm 0.01 \mathrm{a}$ \\
\hline Ozone & $\mathrm{NS}_{1}$ & 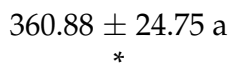 & $\underset{*}{0.12 \pm 0.01 \mathrm{~b}}$ & $\begin{array}{c}0.55 \pm 0.04 \mathrm{a} \\
\mathrm{ns}\end{array}$ & $\begin{array}{c}0.34 \pm 0.03 \\
n s\end{array}$ & $\begin{array}{c}0.00 \pm 0.00 \mathrm{~b} \\
\mathrm{~ns}\end{array}$ \\
\hline & $\mathrm{O}_{0}$ & $227.03 \pm 16.14 \mathrm{a}$ & $0.15 \pm 0.01 \mathrm{a}$ & $0.41 \pm 0.04$ & $0.33 \pm 0.03$ & $0.08 \pm 0.01$ \\
\hline Interactions & $\mathrm{O}_{0.54}$ & $\underset{*}{193.55 \pm} 13.77 \mathrm{~b}$ & $\begin{array}{c}0.12 \pm 0.01 \mathrm{~b} \\
\mathrm{~ns}\end{array}$ & $\begin{array}{c}0.43 \pm 0.04 \\
\mathrm{~ns}\end{array}$ & $\begin{array}{c}0.35 \pm 0.03 \\
\mathrm{~ns}\end{array}$ & $\begin{array}{c}0.08 \pm 0.01 \\
\text { ns }\end{array}$ \\
\hline
\end{tabular}

${ }^{*}$ indicates significant differences among treatments at the $p<0.05$ level by LSD test.

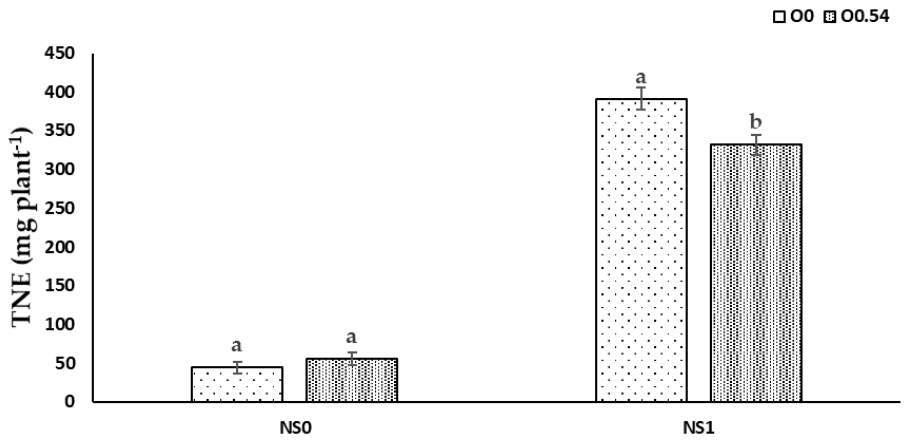

Figure 2. Interactions between fertigation treatments and ozone application on total nitrogen extracted (TNE) from plants. The same letter indicates no significant differences among treatments at the $p<0.05$ level by LSD test. 
The total $\mathrm{N}$ extracted by plants was significantly higher under $\mathrm{O}_{0.18}$ treatment and decreased with the increase in $\mathrm{O}_{3}$ concentration. The lowest value of RNR in pepper plants was presented at $\mathrm{O}_{0.18}$ treatment. Pepper plants grown under $\mathrm{O}_{0.36}$ showed the lowest value of SNR and the highest value of LNR (Table 10).

Table 10. Effects of increasing $\mathrm{O}_{3}$ concentration in fertigation with the standard nutrient solution in total nitrogen extracted from plants (TNE) $\left(\mathrm{mg} \mathrm{plant}^{-1}\right)$ and their distribution in root (RNR), stem (SNR), and leaf (LNR) in C. annum at the end of the experimental period.

\begin{tabular}{ccccc}
\hline & TNE & RNR & SNR & LNR \\
\hline $\mathrm{O}_{0}$ & $390.09 \pm 23.68 \mathrm{~b}$ & $0.13 \pm 0.020 \mathrm{a}$ & $0.54 \pm 0.04 \mathrm{a}$ & $0.33 \pm 0.02 \mathrm{c}$ \\
$\mathrm{O}_{0.18}$ & $438.45 \pm 21.24 \mathrm{a}$ & $0.07 \pm 0.005 \mathrm{~b}$ & $0.55 \pm 0.04 \mathrm{a}$ & $0.41 \pm 0.03 \mathrm{ab}$ \\
$\mathrm{O}_{0.36}$ & $337.70 \pm 19.65 \mathrm{c}$ & $0.11 \pm 0.010 \mathrm{a}$ & $0.46 \pm 0.03 \mathrm{~b}$ & $0.43 \pm 0.03 \mathrm{a}$ \\
$\mathrm{O}_{0.54}$ & $331.67 \pm 20.01 \mathrm{c}$ & $0.11 \pm 0.010 \mathrm{a}$ & $0.55 \pm 0.04 \mathrm{a}$ & $0.34 \pm 0.02 \mathrm{bc}$ \\
\hline
\end{tabular}

Data are the means \pm standard deviation of four samples per treatment. In a column, the same letter indicates no significant differences among treatments at the $p<0.05$ level by LSD test.

\subsubsection{Phosphorus}

Total phosphorus extracted from plants (TPE) increased under fertigation with the standard nutrient solution and without the application of $\mathrm{O}_{3}$. Regarding partitioning in the different organs assessed, the root phosphorus ratio (RPR) decreased under fertigation with the standard nutrient solution and without the application of $\mathrm{O}_{3}$. The stem phosphorus ratio (SPR) showed an opposite trend compared to RPR. The leaf phosphorus ratio (LPR) increased under fertigation with the standard nutrient solution and the application of $\mathrm{O}_{3}$. The fruit phosphorus ratio (FPR) only increased in pepper plants irrigated with water regardless of the $\mathrm{O}_{3}$ application, because under the fertigation with the standard nutrient solution, fruits were not developed (Table 11). There were significant interactions between fertigation treatments and ozone applications in the total phosphorus extracted (TPE) from plants, SPR, and LPR (Figure 3). In the TPE, under $\mathrm{O}_{3}$ supply the increase in total P extraction was significantly higher than without $\mathrm{O}_{3}$ supply when water was applied, but in the case of the standard nutrient solution, the trend was the opposite. Irrigation with water did not result in differences in SPR related to $\mathrm{O}_{3}$ supply, but with the standard nutrient the highest $\mathrm{O}_{3}$ concentration reduced SPR. In LPR, the value was higher under irrigation water and without $\mathrm{O}_{3}$ supply, whereas in the case of the standard nutrient solution, the trend was the opposite.

Table 11. Effects of fertigation treatments (FT) and ozone application on total phosphorus extracted from plants (TPE) $\left(\mathrm{mg} \mathrm{plant}^{-1}\right.$ ) and their distribution in root (RPR), stem (SPR), leaf (LPR), and fruit (FPR) in C. annum at the end of the experimental period. Data are the means \pm standard deviation of four samples per treatment. In a column, the same letter (a-b) indicates no significant differences among treatments at the $p<0.05$ level by LSD test.

\begin{tabular}{cccccccc}
\hline & & TPE & RPR & SPR & LPR & FPR \\
\hline FT & & $*$ & $*$ & $*$ & $*$ & $*$ \\
& $\mathrm{NS}_{0}$ & $29.25 \pm 1.57 \mathrm{~b}$ & $0.16 \pm 0.01 \mathrm{a}$ & $0.27 \pm 0.02 \mathrm{~b}$ & $0.32 \pm 0.02 \mathrm{~b}$ & $0.23 \pm 0.02 \mathrm{a}$ \\
Ozone & $\mathrm{NS}_{1}$ & $49.73 \pm 2.16 \mathrm{a}$ & $0.12 \pm 0.01 \mathrm{~b}$ & $0.52 \pm 0.04 \mathrm{a}$ & $0.37 \pm 0.02 \mathrm{a}$ & $0.00 \pm 0.00 \mathrm{~b}$ \\
& & $*$ & $*$ & $*$ & & $*$ & $\mathrm{~ns}$ \\
& $\mathrm{O}_{0}$ & $42.10 \pm 2.09 \mathrm{a}$ & $0.11 \pm 0.01 \mathrm{~b}$ & $0.43 \pm 0.03 \mathrm{a}$ & $0.32 \pm 0.02 \mathrm{~b}$ & $0.12 \pm 0.01$ \\
Interactions & $\mathrm{O}_{0.54}$ & $26.88 \pm 1.47 \mathrm{~b}$ & $0.17 \pm 0.01 \mathrm{a}$ & $0.36 \pm 0.03 \mathrm{~b}$ & $0.38 \pm 0.03 \mathrm{a}$ & $0.12 \pm 0.01$ \\
\hline
\end{tabular}

* indicates significant differences among treatments at the $p<0.05$ level by LSD test.

The total $\mathrm{P}$ extraction was significantly higher in pepper plants grown under $\mathrm{O}_{0.18}$ treatment, and decreased with increasing $\mathrm{O}_{3}$ concentrations. Pepper plants grown under $\mathrm{O}_{0.54}$ treatment showed the highest value of RPR, whereas the control treatment showed the 
lowest value. Under $\mathrm{O}_{0}$ and $\mathrm{O}_{0.18}$ treatments, pepper plants showed higher values of SPR than $\mathrm{O}_{0.36}$ and $\mathrm{O}_{0.54}$ treatments. Nevertheless, LPR showed an opposite trend (Table 12).
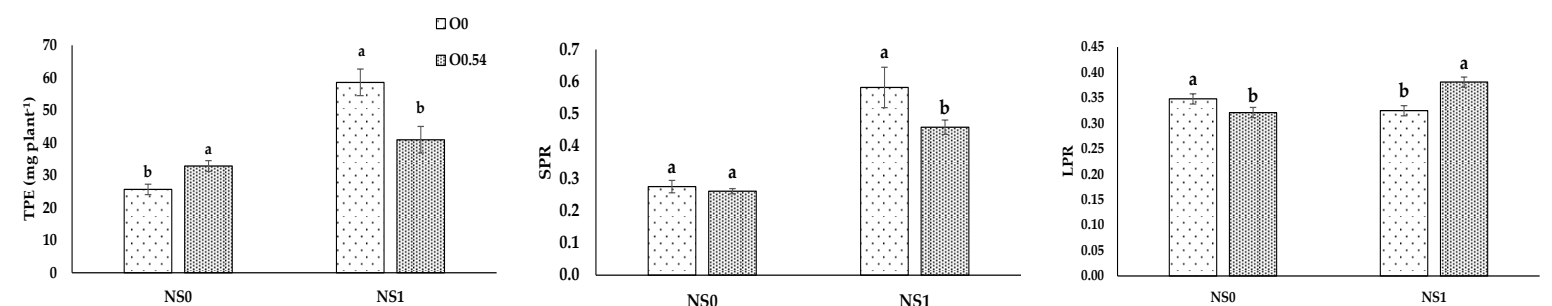

Figure 3. Interactions between fertigation treatments and ozone application on total phosphorus extracted (TPE) from plants, SPR, and LPR. The same letter indicates no significant differences among treatments at the $p<0.05$ level by LSD test.

Table 12. Effects of increasing $\mathrm{O}_{3}$ concentration in the fertigation with the standard nutrient solution in total phosphorus extracted from plants (TPE) $\left(\mathrm{mg} \mathrm{plant}^{-1}\right)$ and their distribution in root (RPR), stem (SPR), and leaf (LPR) in C. annum at the end of the experimental period.

\begin{tabular}{ccccc}
\hline & TPE & RPR & SPR & LPR \\
\hline $\mathrm{O}_{0}$ & $58.55 \pm 2.34 \mathrm{~b}$ & $0.09 \pm 0.01 \mathrm{c}$ & $0.58 \pm 0.04 \mathrm{a}$ & $0.33 \pm 0.01 \mathrm{~b}$ \\
$\mathrm{O}_{0.18}$ & $63.32 \pm 1.74 \mathrm{a}$ & $0.13 \pm 0.01 \mathrm{~b}$ & $0.55 \pm 0.03 \mathrm{a}$ & $0.34 \pm 0.01 \mathrm{~b}$ \\
$\mathrm{O}_{0.36}$ & $53.23 \pm 2.06 \mathrm{c}$ & $0.13 \pm 0.01 \mathrm{~b}$ & $0.48 \pm 0.02 \mathrm{~b}$ & $0.38 \pm 0.02 \mathrm{a}$ \\
$\mathrm{O}_{0.54}$ & $40.91 \pm 1.89 \mathrm{~d}$ & $0.16 \pm 0.01 \mathrm{a}$ & $0.46 \pm 0.02 \mathrm{~b}$ & $0.38 \pm 0.02 \mathrm{a}$ \\
\hline
\end{tabular}

Data are the means \pm standard deviation of four samples per treatment. In a column, the same letter (a-c) indicates no significant differences among treatments at the $p<0.05$ level by LSD test.

\subsubsection{Potassium}

Total potassium extracted from plants (TKE) increased under fertigation with the standard nutrient solution and with the application of $\mathrm{O}_{3}$. For partitioning in the different organs assessed, the root potassium ratio (RKR) decreased under fertigation with the standard nutrient solution regardless of the $\mathrm{O}_{3}$ application. The stem potassium ratio (SKR) increased in pepper plants fertigated with the standard nutrient solution and with the application of $\mathrm{O}_{3}$. The leaf potassium ratio (LKR) decreased under fertigation with the standard nutrient solution and the application of $\mathrm{O}_{3}$. The fruit potassium ratio (FKR) only increased in pepper plants irrigated with water regardless of the $\mathrm{O}_{3}$ application because under the fertigation with the standard nutrient solution, fruits were not developed (Table 13). There were significant interactions between fertigation treatments and ozone application in total potassium extracted (TKE) from plants, RKR, SKR, and LKR (Figure 4). Under water application similar TKE values were found, but the values were higher with $\mathrm{O}_{3}$ in the standard nutrient solution. The root potassium ratio (RKR) and SKR were significantly higher when nutrient solution was applied and under $\mathrm{O}_{3}$ supply. The leaf potassium ratio (LKR) showed an opposite trend considering fertigation with the nutrient solution without $\mathrm{O}_{3}$ supply.

Total $\mathrm{K}$ extraction was significantly higher in pepper plants grown under $\mathrm{O}_{0.18}$ and $\mathrm{O}_{0.36}$ treatments, and decreased with increasing $\mathrm{O}_{3}$ concentrations; the control treatment showed the lowest value. The lowest value for RKR and SKR was found in pepper plants grown under the control treatment $\left(0 \mathrm{mg} \mathrm{L}^{-1}\right.$ of $\left.\mathrm{O}_{3}\right)$. The LKR was highest for $\mathrm{O}_{0}$ and $\mathrm{O}_{0.36}$ treatments (Table 14). 
Table 13. Effects of fertigation treatments (FT) and ozone application on total potassium extracted from plants (TKE) $\left(\mathrm{mg} \mathrm{plant}^{-1}\right.$ ) and their distribution in root (RKR), stem (SKR), leaf (LKR), and fruit (FKR) in C. annum at the end of the experimental period. Data are the means \pm standard deviation of four samples per treatment. In a column, the same letter $(\mathrm{a}-\mathrm{b})$ indicates no significant differences among treatments at the $p<0.05$ level by LSD test.

\begin{tabular}{|c|c|c|c|c|c|c|}
\hline & & TKE & RKR & SKR & LKR & FKR \\
\hline FT & & * & * & * & * & * \\
\hline & $\mathrm{NS}_{0}$ & $208.16 \pm 15.26 b$ & $0.09 \pm 0.01 \mathrm{a}$ & $0.34 \pm 0.03 \mathrm{~b}$ & $0.44 \pm 0.02 \mathrm{a}$ & $0.12 \pm 0.01 \mathrm{a}$ \\
\hline Ozone & $\mathrm{NS}_{1}$ & $\underset{*}{389.49} \underset{ }{20.35} \mathrm{a}$ & $\begin{array}{c}0.06 \pm 0.01 \mathrm{~b} \\
\mathrm{~ns}\end{array}$ & $\begin{array}{c}0.52 \pm 0.04 \mathrm{a} \\
*\end{array}$ & $\underset{*}{0.40 \pm 0.01 \mathrm{~b}}$ & $\begin{array}{c}0.00 \pm 0.00 \mathrm{~b} \\
\mathrm{~ns}\end{array}$ \\
\hline & $\mathrm{O}_{0}$ & $279.34 \pm 19.38 b$ & $0.07 \pm 0.02$ & $0.38 \pm 0.03 b$ & $0.48 \pm 0.03 \mathrm{a}$ & $0.12 \pm 0.01$ \\
\hline Interactions & $\mathrm{O}_{0.54}$ & $\underset{*}{318.31 \pm} 15.17 \mathrm{a}$ & $0.09 \pm 0.02$ & $\begin{array}{c}0.47 \pm 0.04 \mathrm{a} \\
*\end{array}$ & $0.37 \pm 0.03 \mathrm{~b}$ & $\begin{array}{c}0.13 \pm 0.01 \\
\text { ns }\end{array}$ \\
\hline
\end{tabular}

${ }^{*}$ indicates significant differences among treatments at the $p<0.05$ level by LSD test.
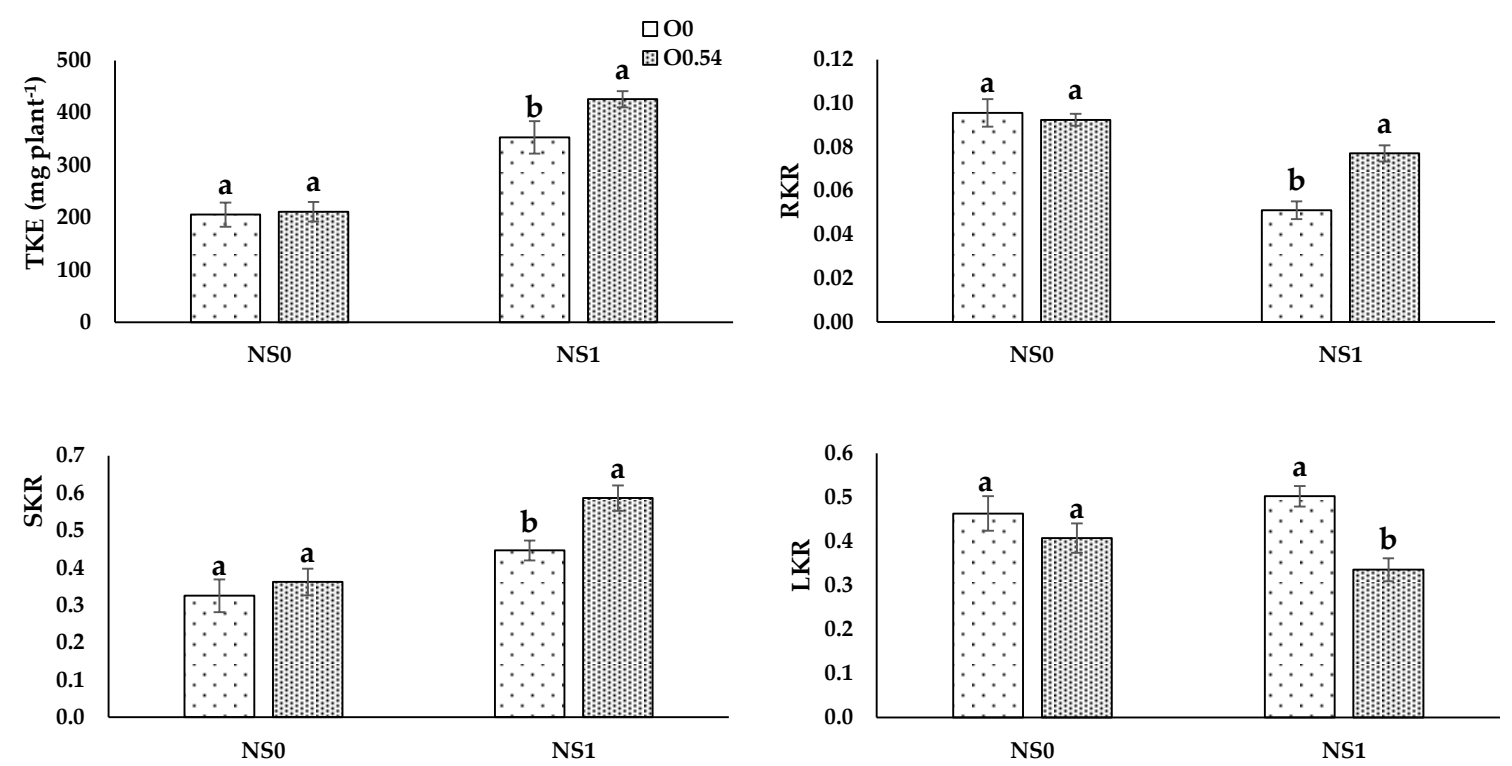

Figure 4. Interactions between fertigation treatments and ozone application on total potassium extracted (TKE) from plants, RKR, SKR, and LKR. The same letter indicates no significant differences among treatments at the $p<0.05$ level by LSD test.

Table 14. Effects of increasing $\mathrm{O}_{3}$ concentration in the fertigation with the standard nutrient solution in total potassium extracted from plant (TKE) $\left(\mathrm{mg} \mathrm{plant}^{-1}\right)$ and their distribution in root (RKR), stem (SKR), and leaf (LKR) in C. annum at the end of the experimental period.

\begin{tabular}{|c|c|c|c|c|}
\hline & TKE & RKR & SKR & LKR \\
\hline $\mathrm{O}_{0}$ & $353.17 \pm 17.19 c$ & $0.05 \pm 0.007 \mathrm{~b}$ & $0.45 \pm 0.04 \mathrm{~b}$ & $0.50 \pm 0.04 \mathrm{a}$ \\
\hline $\mathrm{O}_{0.18}$ & $484.78 \pm 20.45 a$ & $0.06 \pm 0.005 \mathrm{ab}$ & $0.61 \pm 0.04 \mathrm{a}$ & $0.34 \pm 0.03 b$ \\
\hline $\mathrm{O}_{0.36}$ & $\begin{array}{c}455.79 \pm 23.49 \\
\mathrm{ab}\end{array}$ & $0.07 \pm 0.006 \mathrm{ab}$ & $0.60 \pm 0.04 \mathrm{a}$ & $0.53 \pm 0.04 a$ \\
\hline $\mathrm{O}_{0.54}$ & $425.82 \pm 24.28 b$ & $0.08 \pm 0.005 a$ & $0.59 \pm 0.05 a$ & $0.34 \pm 0.03 b$ \\
\hline
\end{tabular}

Data are the means \pm standard deviation of four samples per treatment. In a column, the same letter $(\mathrm{a}-\mathrm{c})$ indicates no significant differences among treatments at the $p<0.05$ level by LSD test.

\section{Discussion}

Coll et al. [29] defined as "unfavorable conditions" those in which the environmental conditions deviate from those considered optimal, and plants modify their development to adapt to them, producing enzymes or accelerating their development. These unfavorable conditions are known as biotic or abiotic stress. 
Under stress conditions such as high temperature [30], waterlogging [31], salinity [32], and hydric and nutrient deficiencies [25], plants must change their physiology and increase their efficiency so as to use few nutrients available to fulfill their development cycles as occurs under $\mathrm{O}_{0}$.

The supply of $\mathrm{O}_{3}$ dissolved in irrigation water led to an autolysis process in the matrix substrate, generating active oxygen species $\left(\mathrm{H}_{2} \mathrm{O}_{2}, \mathrm{OH}^{-}, \mathrm{O}_{2}{ }^{-}\right)$[33] and an increase in $\mathrm{pH}$ [34]. The chemical autolysis is potentiated because $\mathrm{O}_{3}$ reacts with molecules containing nitrogen, hydrogen, chlorine, or bromine. Moreover, there should not be transference to the environment because $\mathrm{O}_{3}$ solubility in water is in the range of $780 \mathrm{mg} \mathrm{L}^{-1}$ at $10^{\circ} \mathrm{C}$ to $270 \mathrm{mg} \mathrm{L}^{-1}$ at $40^{\circ} \mathrm{C}$, higher that our tested concentrations. For these reasons, we suggest that under the conditions assessed in our experiment, pepper plants should have higher $\mathrm{O}_{2}$ availability. Sloan and Engelke [35] reported similar conditions in Agrostis stolonifera using aerated nutrient solution and $\mathrm{O}_{3}$.

Considering $\mathrm{O}_{2}$ concentration in the nutritive solution, studies carried out applying low concentrations of $\mathrm{O}_{2}$ in the nutrient solution in corn plants showed a decrease in biomass [36], especially in root biomass [37]. These results could be considered similar to $\mathrm{O}_{0}$ compared to $\mathrm{O}_{0.54}$ in the first experiment. Although in $\mathrm{O}_{0}$ there were no anoxic conditions that may cause a shortage of $\mathrm{O}_{2}$, its concentration was lower than in $\mathrm{O}_{0.54}$.

Suyantohadi et al. [38] reported beneficial effects applying high levels of dissolved $\mathrm{O}_{2}$ (from 20 to $30 \mathrm{mg} \mathrm{L}^{-1}$ ) in hydroponically grown lettuce. Experiments with cucumbers and peppers had relatively little success in improving the yield of fruits exposed to an increase in dissolved $\mathrm{O}_{2}$ in the nutrient solution [39]. In addition, $\mathrm{O}_{2}$ concentrations higher than $30 \mathrm{mg} \mathrm{L}^{-1}$ generated detrimental production in tomato under a hydroponic system [40].

Considering $\mathrm{O}_{3}$ supplies, Kobayashi et al. [41], using $\mathrm{O}_{3}$ microbubbles at 0.2 ppm in the nutrient solution, reported no adverse effects on lettuce growth. Similar results were reported by Zheng et al. [42] (2-4 $\left.\mathrm{mg} \mathrm{L}^{-1}\right)$ in lettuce and by Ohashi-Kaneko et al. [43] $\left(0-10 \mathrm{mg} \mathrm{L}^{-1}\right)$ in tomato plants. Nevertheless, Najarian et al. [44] reported a higher growth of cucumber plants with an $\mathrm{O}_{3}$ dosage of $0.5 \mathrm{mg} \mathrm{L}^{-1}$. Similarly, irrigation with ozonated water at $0.5 \mathrm{mg} \mathrm{L}^{-1}$ increased the fresh weight of bok choy and Chinese spinach [45]. This increase in biomass can be related to the enhancement of root respiration by the presence of ozonated water [46].

The data obtained in our experiment show an increase in biomass especially accumulated in the stem fraction of pepper plants through the application of $\mathrm{O}_{3}$ in the nutritive solution treatments, in agreement with the results reported by Graham et al. [18] in tomato. Nevertheless, the highest total dry weight in the second experiment was associated with the $\mathrm{O}_{0.18}$ and $\mathrm{O}_{0.36}$ treatments but not at the highest concentration, which can be associated with the higher sensitivity to elevated $\mathrm{O}_{3}$ reported by Wittig et al. [47].

In our experiment, pepper plants irrigated only with water showed the highest relative water content. These results agree with those proposed by Morales et al. [48], who compared water and nutrient solution treatments and reported an osmotic effect caused by an increase in salts due to the presence of fertilizers, which can restrict the root water uptake and affect the plant water status. On the same hand, Parra-Terraza et al. [49] reported that if there is an increase in nutrient concentration in the nutrient solution, the osmotic potential increases in absolute value, decreasing the free energy, and consequently the uptake processes of water and some nutrients are affected.

With respect to $\mathrm{O}_{3}$ supply, there were no significant differences in relative water content in pepper plants, but when $\mathrm{O}_{3}$ concentration increased in the nutrient solution, there was also an increase in RWC in pepper plants. After reviewing previous literature, we found no references about the modifications of the water status of one species after the application of ozonated water. Wilkinson and Davies [50] reported that under a combined $\mathrm{O}_{3}$ stress caused by atmospheric concentrations of 60-80 ppb and drought conditions, there was an ethylene-dependent reduction in the sensitivity of stomata to abscisic acid (ABA) and repressed stomatal closure, which would mean a loss of water and therefore lower values of RWC. Nevertheless, under well-watered conditions, $\mathrm{O}_{3}$ often reduces stomatal 
aperture $[47,51]$. Therefore, considering that our experiment was conducted under wellwatered conditions, the results reported in $\mathrm{O}_{0.54}$ treatment may be due to higher sensitivity to elevated $\mathrm{O}_{3}$.

Pepper plants did not show significant differences in leaf area under water irrigation or fertigation with a standard nutrient solution with or without the application of $\mathrm{O}_{3}$. Nevertheless, the increase in $\mathrm{O}_{3}$ supplies increased leaf area but at $\mathrm{O}_{0.54}$, leaf area in pepper plants showed a decline. These results were in line with Chan et al. [45], who reported that the irrigation by ozonated water for one month increased the leaf area of bok choy and Chinese spinach (doses from $0.5 \mathrm{mg} \mathrm{L}^{-1}$ to $1.5 \mathrm{mg} \mathrm{L}^{-1}$ ). In addition, Peykanpour et al. [46] reported that the increase in leaf area in cucumber plants was associated with the increase in $\mathrm{O}_{3}$ concentration from 0 to $1 \mathrm{mg} \mathrm{L}^{-1}$. Nevertheless, Najarian et al. [44] reported an increase in leaf area in cucumber plants up to $0.5 \mathrm{mg} \mathrm{L}^{-1} \mathrm{O}_{3}$ concentration.

As far as physiological parameters were concerned, in our experiment, the application of $\mathrm{O}_{3}$ resulted in an increase in $\mathrm{Chl} \mathrm{b}$ and $\mathrm{Chl} \mathrm{a}+\mathrm{b}$ under $\mathrm{O}_{0.18}$, in line with the results proposed by Sloan and Engelke [35], who reported a significant increase in chlorophyll concentration in Agrostis stolonifera under the application of $\mathrm{O}_{3}$. Moreover, our results for pigment concentrations in pepper plants under $\mathrm{O}_{0.36}$ were in line with the results proposed by Chan et al. [45], who noted not significant differences in chlorophyll concentration under the application of ozonated water (doses from $0.5 \mathrm{mg} \mathrm{L}^{-1}$ to $1.5 \mathrm{mg} \mathrm{L}^{-1}$ ) in vegetable species (choy sum, bok choy, green mustard, and Chinese spinach) in the vegetative stage. Similarly, Martínez-Sánchez and Aguayo [19] reported that the application of ozonated water affected neither the photosynthesis rate nor the development of grafted watermelon seedlings. In addition, Paniagua [52] reported no effects in $\mathrm{Chl}$ a and $\mathrm{Chl} \mathrm{a+b}$ associated with the action of this oxidizing compound in Cordyline fruticosa plants var. "Red Edge" fertigated with different mixtures of $\mathrm{H}_{2} \mathrm{O}_{2}$. In our experiment, we reported a reduction in $\mathrm{Chl} \mathrm{a}, \mathrm{Chl} b$, and $\mathrm{Chl} \mathrm{a}+\mathrm{b}$ concentration under $\mathrm{O}_{0.54}$, which can be related to the possible $\mathrm{O}_{3}$ transference to the environment associated with a significant decrease in chlorophyll concentration, as has been reported for wheat [53] and lettuce [54] under environmental pollution.

The concentration of total soluble sugars in leaves can be considered the balance of bioassimilated generation processes and respiration losses. Sugars in turn are important substrates in the respiration process, which ensure plants have sufficient energy necessary to increase the intensity of some metabolic processes activated under stress factors [55]. In previous literature, Nicoletto et al. [56] reported no effect of $\mathrm{O}_{3}$ supply on leaf total soluble sugars in a forcing closed system process of Cichorium intybus. Similarly, the application of $\mathrm{O}_{3}$ in gaseous form to the soil did not result in changes in leaf total soluble sugars in Fagus sylvatica. These results agree with the data obtained from our experiment, except for the case of $\mathrm{O}_{0.18}$, which presented a significantly lower leaf total soluble sugars concentration. This fact can be associated with a differential carbon partitioning and also due to the dilution effect since $\mathrm{O}_{0.18}$ showed the highest TDW [57].

Proline is a biochemical indicator related to stress tolerance in biotic and abiotic stress [58]. For instance, the intervention of this osmolyte has been reported in plants grown under a water deficit [59,60], saline conditions [4], changing light conditions [61], heavy metal concentrations [62], and with pests and diseases [63].

Although it has been reported that under nutrient imbalances, including mineral toxicities and deficiencies of nitrogen, phosphorus, or potassium, there is an increase in proline concentration [64], our experiment showed a decline in proline concentration in pepper plants irrigated only with water.

A significant decrease in leaf proline concentration was evident at higher $\mathrm{O}_{3}$ concentrations. In the literature, there are no references about the effects of the supply of $\mathrm{O}_{3}$ in fertigation on leaf proline concentration. Nevertheless, under $\mathrm{O}_{3}$ tropospheric pollution, El-Khatib [65] reported an increase in leaf proline concentration in several species such as Senecio vulgaris, Malva parviflora, Sonchus oleraceus, Medicago sativa, and Melilotus indicus under increasing $\mathrm{O}_{3}$ concentrations (from $50 \mathrm{ppb}$ to $100 \mathrm{ppb}$ ). The decrease in leaf proline concentration in this study may suggest that the application of $\mathrm{O}_{3}$ in the standard nutrient 
solution did not result in oxidative stress in pepper plants, which is associated with the increase in different osmolytes such as proline.

It is well known that $\mathrm{N}, \mathrm{P}$, and $\mathrm{K}$ are essential for the adequate development of a crop, the latter especially in the stages of flowering and fruit setting. Therefore, these macronutrients are consumed in high amounts and if there is any deficiency of one of them, there is a reduction in crop yield [66], as happened in our treatment with only water irrigation. The lower $\mathrm{N}, \mathrm{P}$, and $\mathrm{K}$ extraction in plants grown under water irrigation against fertigation with the standard nutrient solution was in line with the findings of Marschner [67], mainly based on the availability or not for nutrient uptake. In addition, sterilization with ozonated water could increase the water and mineral uptake by the root system of the plant [43]. Nevertheless, Martínez-Sánchez and Aguayo [19] used ozonated fertigation $(750 \mathrm{mV})$ in Capsicum seedlings and reported no differences in leaf $\mathrm{N}$ concentration, but significantly lower concentrations of $\mathrm{P}$ and $\mathrm{K}$ compared to the control treatment without $\mathrm{O}_{3}$. The results of our experiment showed lower plant $\mathrm{N}$ uptake but a similar leaf nitrogen ratio under increasing $\mathrm{O}_{3}$ concentrations. Plant total $\mathrm{P}$ extraction showed a significant decrease compared to the control treatment, in line with the results reported by Martínez-Sánchez and Aguayo [19], who noted the same trend. Nevertheless, the increase in plant total $\mathrm{K}$ extraction showed an opposite trend compared with the results obtained by Martínez-Sánchez and Aguayo [19].

For $\mathrm{O}_{3}$ concentration, the highest $\mathrm{N}, \mathrm{P}$, and $\mathrm{K}$ extractions were evident in pepper plants grown under $\mathrm{O}_{0.18}$ treatment. Potassium extraction increased from $\mathrm{O}_{0}$ to $\mathrm{O}_{0.36}$, but at the highest concentration $\left(0.54 \mathrm{mg} \mathrm{L}^{-1}\right)$ showed a decrease compared to $\mathrm{O}_{0.18}$, which can be associated with the fact that $\mathrm{K}$ is the most sensitive nutrient to the lack of $\mathrm{O}_{2}$ due to its efflux to the medium [68].

Nutrient uptake processes are linked to $\mathrm{H}^{+}$-pumps via cotransport, antiport, and uniport mechanisms, which are related to the $\mathrm{O}_{2}$ availability in the nutrient solution, as reported by Clarkson and Lüttge [69]. Therefore, this fact can be the reason for the increase in TNE, TPE, and TKE under $\mathrm{O}_{0.18}$ treatment compared to $\mathrm{O}_{0}$ treatment. Nevertheless, at higher $\mathrm{O}_{3}$ concentrations, an antagonistic effect may occur as a consequence of a reduction in transpiration and an impairment of the active transport of $\mathrm{N}, \mathrm{P}$, and $\mathrm{K}$, which can be responsible for disruptions in the nutrient transport from roots to shoots [70], as occurs when comparing $\mathrm{O}_{0.36}$ to $\mathrm{O}_{0.54}$, since we noted an increase in RNR, RPR, and RKR and a decrease in stem and leaf ratios.

\section{Conclusions}

The $\mathrm{O}_{3}$ supply via fertigation increased growth evaluated as biomass produced but showed lower root development. This higher biomass may be associated with higher plant $\mathrm{N}$ and $\mathrm{K}$ uptake. The recommended dosage of $\mathrm{O}_{3}$ is from 0.18 to $0.36 \mathrm{mg} \mathrm{L}^{-1}$. The increase in stem and leaf weight ratios can be ascribed to a higher leaf area and an increase in chlorophyll concentration. Moreover, a higher synthesis of bioassimilates favoring plant growth may be related to the higher values of N, P, and $\mathrm{K}$ uptake. The results obtained with the $\mathrm{O}_{3}$ supply in fertigation in pepper plants in these experiments are very encouraging. Nevertheless, higher dosages such as $0.54 \mathrm{mg} \mathrm{L}^{-1}$ of $\mathrm{O}_{3}$ should be studied in more depth in order to assess oxidative and/or phytotoxic damage associated with the supply of $\mathrm{O}_{3}$. Comparative studies with other oxidizing compounds and dissolved $\mathrm{O}_{3}$ supply should be conducted in order to check their implementation in intensive greenhouse horticulture.

Author Contributions: Conceptualization, M.T.L.; methodology, M.T.L. and P.G.-C.; software, J.C.; validation, M.T.L.; formal analysis, J.C. and J.F.M.; investigation, J.C.; resources, M.T.L.; data curation, M.T.L.; writing - original draft preparation, M.T.L.; writing—review and editing, P.G.-C.; visualization, M.T.L.; supervision, M.T.L. All authors have read and agreed to the published version of the manuscript.

Funding: This research received no external funding.

Institutional Review Board Statement: Not applicable. 
Informed Consent Statement: Not applicable.

Data Availability Statement: Not applicable.

Acknowledgments: We thank the Evoindustrias company for providing and calibrating the $\mathrm{O}_{3}$ equipment and monitoring the test for its transfer to the sector.

Conflicts of Interest: The authors declare no conflict of interest.

\section{References}

1. Mashhor, M.V.; Mashal, M.; Hashemi Garmdareh, S.E.; Reca, J.; Lao, M.T.; Veravipour, M.; Ebrahimian, H. Growth, yield, and water productivity responses of pepper to sub-irrigated planter systems in a greenhouse. Sustainability 2020, 12, 1100. [CrossRef]

2. Urrestarazu, M. Manual Práctico del Cultivo sin Suelo e Hidroponía; Mundi Prensa Libros: Ediciones Paraninfo, Spain, $2015 ;$ p. 278.

3. Plaza, B.M. Estudio de la Viabilidad de la Reutilización de Lixiviados Para la Producción de plantas Ornamentales, en el Marco de una Producción Sostenible. Ph.D. Dissertation, University of Almería, Almería, Spain, 2013; p. 282.

4. García-Caparrós, P.; Llanderal, A.; Maksimovic, I.; Lao, M.T. Cascade cropping system with horticultural and ornamental plants under greenhouse conditions. Water 2018, 10, 125. [CrossRef]

5. Junior, R.S. Enfermedades fúngicas del pimiento en España. Vida Rural 1998, 68, 56-58.

6. Palazón, C.; Palazón, I. Estudios epidemiológicos sobre la «tristeza» del pimiento en la zona del Valle Medio del Ebro. Bol. San. Veg. Plagas. 1989, 15, 233-262.

7. Treceño, A.M.; de Cal, A.; Moreno, P.M.; Aranda, J.M.L. Alternativas químicas al bromuro de metilo en viveros de fresa en España. Phytoma 2004, 161, 14-19.

8. Acuña, S.; Bonachela, S.; Magán, J. Técnicas de Enriquecimiento de Oxígeno en Cultivo de Melón en Perlita; Estación Experimental de la Fundación de Cajamar. El Ejido: Almería, Spain, 2006; 6p.

9. Urrestarazu, M. Chapter 5. Bioseguridad, química verde y sostenible en la horticultura protegida ¿cómo usar las mezclas peroxiacéticas de forma segura en la horticultura protegida. In Manual de Tomate Kumara; Ediciones Universidad de Tarapacá: Arica, Chile, 2013; p. 59.

10. Cuervo-Usán, Y.; Tornos-Mauri, P.; Hernández-Domínguez, J.C.; Orihuela-Calvo, D.; Domínguez-Hernández, M.E.; MorenoMartínez, E. Eficacia de peróxidos en la desinfección de suelos aptos para el cultivo de fresa en el Mediterráneo. Rev. Fitotec. Mex. 2014, 37, 393-398. [CrossRef]

11. Bertrand, B. Efficiency of Ozone-Based Advanced Oxidation Processes in Treating Recirculating Irrigation Water. Ph.D. Thesis, Dissertation, University of Guelph, Ontario, ON, Canada, 2020; p. 159.

12. Cullen, P.J.; Valdramidis, V.P.; Tiwari, B.K.; Patil, S.; Bourke, P.C.P. Ozone processing for food preservation: An overview on fruit juice treatments. Ozone Sci. Engin. 2010, 32, 166-179. [CrossRef]

13. Dennis, R.; Pourdeyhimi, B.; Cashion, A.; Emanuel, S.; Hubbard, D. Durability of disposable N95 mask material when exposed to improvised ozone gas disinfection. J. Sci. Med. 2020, 2, 1.

14. McCarthy, J.E.; Lattanzio, R.K. Ozone air Quality Standards: EPA's 2015 Revision; Library of Congress, Congressional Research Service; EPA: Washington, DC, USA, 2014; p. 23.

15. Macdowall, F.D.H.; Mukammal, E.I.; Cole, A.F.W. Direct correlation of air-polluting ozone and tobacco weather fleck. Can. J. Plant Sci. 1964, 44, 410-417. [CrossRef]

16. Kumari, S.; Agrawal, M.; Tiwari, S. Impact of elevated $\mathrm{CO}_{2}$ and elevated $\mathrm{O}_{3}$ on Beta vulgaris L.: Pigments, metabolites, antioxidants, growth and yield. Environ. Pollut. 2013, 174, 279-288. [CrossRef] [PubMed]

17. Graham, T.; Zhang, P.; Zheng, Y.; Dixon, M.A. Phytotoxicity of aqueous ozone on five container-grown nursery species. HortScience 2009, 44, 774-780. [CrossRef]

18. Graham, T.; Zhang, P.; Woyzbun, E.; Dixon, M. Response of hydroponic tomato to daily applications of aqueous ozone via drip irrigation. Sci. Hortic. 2011, 129, 464-471. [CrossRef]

19. Martínez-Sánchez, A.; Aguayo, E. Effect of irrigation with ozonated water on the quality of capsicum seedlings grown in the nursery. Agric. Water Manag. 2019, 221, 547-555. [CrossRef]

20. TopOzono. 2010. Available online: https://topozono.com/ (accessed on 15 September 2020).

21. García-Caparrós, P.; Llanderal, A.; Pestana, M.; Correia, P.J.; Lao, M.T. Tolerance mechanisms of three potted ornamental plants grown under moderate salinity. Sci. Hortic. 2016, 201, 84-91. [CrossRef]

22. Ben Amor, N.; Ben Hamed, K.; Debez, A.; Grignon, C.; Abdelly, C. Physiological and antioxidant responses of the perennial halophyte Crithmum maritimum to salinity. Plant Sci. 2005, 168, 889-899. [CrossRef]

23. García-Caparrós, P.; Llanderal, A.; El-Tarawy, A.; Majsztrik, J.; Lao, M.T. Response of container-grown Confetti tree irrigated with runoff water. HortTech. 2017, 27, 625-630. [CrossRef]

24. Wellburn, A. The spectral determination of chlorophylls a and b, as well as total carotenoids, using various solvent with spectrophotometers of different resolution. J. Plant Physiol. 1994, 144, 307-313. [CrossRef]

25. Irigoyen, J.J.; Emerich, D.W.; Sánchez-Díaz, M. Water stress induced changes in concentrations of proline and total soluble sugars in nodulated alfalfa (Medicago sativa) plants. Physiol. Plant. 1992, 84, 55-60. [CrossRef] 
26. Cataldo, D.A.; Haroon, M.; Schrader, L.E.; Young, V.L. Rapid colorimetric determination of nitrate in plant tissue by nitration of salicylic acid. Comm. Soil Sci. Plant Anal. 1975, 6, 71-80. [CrossRef]

27. Hogue, E.; Wilcow, G.E.; Cantliffe, D.J. Effect of soil P on phosphate fraction in tomato leaves. J. Am. Soc. Hort. Sci. 1970, 95, 174-176.

28. Lachica, M.; Aguilar, A.; Yanez, J. Análisis foliar: Métodos utilizados en la Estación Experimental del Zaidín. Anal. Edafol. Agrobiol. 1973, 32, 1033-1047.

29. Coll, J.B.; Rodrigo, G.N.; García, B.S.; Tamés, R.S. Fisiología Vegetal; Comercial Grupo ANAYA: Madrid, Spain, $2019 ;$ p. 568.

30. Chaves-Barrantes, N.F.; Gutiérrez-Soto, M.V. Respuestas al estrés por calor en los cultivos. I. aspectos moleculares, bioquímicos y fisiológicos. Agron. Mesoam. 2017, 28, 237-253. [CrossRef]

31. Pardos, J.A. Respuestas de las plantas al anegamiento del suelo. Forest Syst. 2008, 13, 101-107. [CrossRef]

32. Dell'Amico, J.M.; Parra, M. Efecto del estrés por $\mathrm{NaCl}$ en el contenido de cloruros, el potencial osmótico real y el crecimiento de dos cultivares de tomate cubanos. Cultiv. Trop. 2005, 26, 39-44.

33. Tomiyasu, H.; Fukutomi, H.; Gordon, G. Kinetics and mechanism of ozone decomposition in basic aqueous solution. Inorg. Chem. 1985, 24, 2962-2966. [CrossRef]

34. Oyama, S.T. Chemical and catalytic properties of ozone. Catal. Rev. 2000, 42, 279-322. [CrossRef]

35. Sloan, J.J.; Engelke, M.C. Effect of ozonated water on creeping bentgrass growth in a sand medium. HortTechnology 2005, 15, 148-152. [CrossRef]

36. Atwell, B.J.; Thomson, C.J.; Greenway, H.; Ward, G.; Waters, I. A study of the impaired growth of roots of Zea mays seedlings at low oxygen concentrations. Plant Cell Environ. 1985, 8, 179-188.

37. Mexal, J.; Fisher, J.T.; Osteryoung, J.; Reid, C.P. Oxygen availability in polyethylene glycol solutions and its implications in plant-water relations. Plant Physiol. 1975, 55, 20-24. [CrossRef] [PubMed]

38. Suyantohadi, A.; Kyoren, T.; Hariadi, M.; Purnomo, M.H.; Morimoto, T. Effect of high concentrated dissolved oxygen on the plant growth in a deep hydroponic culture under a low temperature. IFAC Proc. 2010, 43, 251-255. [CrossRef]

39. Ehret, D.L.; Edwards, D.; Helmer, T.; Lin, W.; Jones, G.; Dorais, M.; Papadopoulos, A.P. Effects of oxygen-enriched nutrient solution on greenhouse cucumber and pepper production. Sci. Hortic. 2010, 125, 602-607. [CrossRef]

40. Zheng, Y.; Wang, L.; Dixon, M. An upper limit for elevated root zone dissolved oxygen concentration for tomato. Sci. Hortic. 2007, 113, 162-165. [CrossRef]

41. Kobayashi, F.; Ikeura, H.; Ohsato, S.; Goto, T.; Tamaki, M. Ozone microbubbles as disinfection in nutrient solution and their effects on composition of fertilizer and growth of cultivated plants. Biol. Engin. Trans. 2012, 5, 137-146. [CrossRef]

42. Zheng, L.; Liu, C.; Song, W. Effect of ozonated nutrient solution on the growth and root antioxidant capacity of substrate and hydroponically cultivated lettuce (Lactuca sativa). Ozone Sci. Engin. 2020, 42, 286-292. [CrossRef]

43. Ohashi-Kaneko, K.; Yoshii, M.; Isobe, T.; Park, J.S.; Kurata, K.; Fujiwara, K. Nutrient solution prepared with ozonated water does not damage early growth of hydroponically grown tomatoes. Ozone Sci. Engin. 2009, 31, 21-27. [CrossRef]

44. Najarian, M.; Mohammadi-Ghehsareh, A.; Fallahzade, J.; Peykanpour, E. Responses of cucumber (Cucumis sativus L.) to ozonated water under varying drought stress intensities. J. Plant Nutr. 2018, 41, 1-9. [CrossRef]

45. Chan, G.Y.; Li, Y.; Lam, E.K.; Chen, C.Y.; Lin, L.; Luan, T.; Yeung, P.H. Effects of ozonated water on antioxidant and phytohormones level of vegetable. In Proceedings of the IOA Conference and Exhibition, Valencia, Spain, 29-31 October 2007 ; p. 1.

46. Peykanpour, E.; Ghehsareh, A.M.; Fallahzade, J.; Najarian, M. Interactive effects of salinity and ozonated water on yield components of cucumber. Plant Soil Environ. 2016, 62, 361-366. [CrossRef]

47. Wittig, V.E.; Ainsworth, E.A.; Naidu, S.L.; Karnosky, D.F.; Long, S.P. Quantifying the impact of current and future tropospheric ozone on tree biomass, growth, physiology and biochemistry: A quantitative meta-analysis. Glob. Chang. Biol. 2009, 15, 396-424. [CrossRef]

48. Morales, D.; Bolarín, M.D.C.; Cayuela, E. Respuesta de plantas de arroz (Oryza sativa L.) a la aplicación de diferentes niveles de $\mathrm{NaCl}$. I. Crecimiento y relaciones hídricas. Cultiv. Trop. 2006, 27, 27-32.

49. Parra Terraza, S. Cloruro/aniones y sodio/cationes en soluciones nutritivas y composición mineral de cultivares de tomate. Terra Latinoam. 2016, 34, 219-227.

50. Wilkinson, S.; Davies, W.J. Drought, ozone, ABA and ethylene: New insights from cell to plant to community. Plant Cell Environ. 2010, 33, 510-525. [CrossRef] [PubMed]

51. Kangasjärvi, J.; Jaspers, P.; Kollist, H. Signalling and cell death in ozone-exposed plants. Plant Cell Environ. 2005, 28, 1021-1036. [CrossRef]

52. Paniagua Salvador, F. Empleo de $\mathrm{H}_{2} \mathrm{O}_{2}$ para la Desinfección de Soluciones de Lixiviación Empleadas en Fertirrigación. Degree Thesis, University of Almeria, Almeria, Spain, 2018; p. 92.

53. Meyer, U.; Köllner, B.; Willenbrink, J.; Krause, G.H.M. Effects of different ozone exposure regimes on photosynthesis, assimilates and thousand grain weight in spring wheat. Agric. Ecosys. Environ. 2000, 78, 49-55. [CrossRef]

54. Calatayud, A.; Barreno, E. Response to ozone in two lettuce varieties on chlorophyll a fluorescence, photosynthetic pigments and lipid peroxidation. Plant Physiol. Biochem. 2004, 42, 549-555. [CrossRef]

55. Kleiber, T.; Borowiak, K.; Schroeter-Zakrzewska, A.; Budka, A.; Osiecki, S. Effect of ozone treatment and light colour on photosynthesis and yield of lettuce. Sci. Hortic. 2017, 217, 130-136. [CrossRef] 
56. Nicoletto, C.; Maucieri, C.; Sambo, P. Effects on water management and quality characteristics of ozone application in chicory forcing process: A pilot system. Agronomy 2017, 7, 29. [CrossRef]

57. Ap Rees, T. Control of carbon partitioning in plants. In Proceedings-Phytochemical Society of Europe; Oxford University Press: Oxford, England, 1993; p. 35.

58. Serraj, R.; Sinclair, T.R. Osmolyte accumulation: Can it really help increase crop yield under drought conditions? Plant Cell Environ. 2002, 25, 333-341. [CrossRef] [PubMed]

59. Paleg, L.G.; Stewart, G.R.; Bradbeer, J.W. Proline and glycine betaine influence protein solvation. Plant Physiol. 1984, 75, 974-978. [CrossRef]

60. Chávez Suárez, L.; Álvarez Fonseca, A.; Ramírez Fernández, R. Apuntes sobre algunos reguladores del crecimiento vegetal que participan en la respuesta de las plantas frente al estrés abiótico. Cultiv. Trop. 2012, 33, 47-56.

61. García-Caparrós, P.; Almansa, E.M.; Chica, R.M.; Lao, M.T. Effects of artificial light treatments on growth, mineral composition, physiology, and pigment concentration in Dieffenbachia maculata "Compacta" plants. Sustainability 2019, 11, 2867. [CrossRef]

62. Saradhi, P.P. Proline accumulation under heavy metal stress. J. Plant Physiol. 1991, 138, 554-558.

63. Christgen, S.L.; Becker, D.F. Role of proline in pathogen and host interactions. Antiox. Redox Signal. 2019, 30, 683-709. [CrossRef] [PubMed]

64. Göring, H.; Thien, B.H. Influence of nutrient deficiency on proline accumulation in the cytoplasm of Zea mays L. seedlings. Biochem. Physiol. Pflanzen 1979, 174, 9-16. [CrossRef]

65. El-Khatib, A.A. The response of some common Egyptian plants to ozone and their use as biomonitors. Environ. Pollut. 2003, 124, 419-428. [CrossRef]

66. Kim, Y.X.; Kim, T.J.; Lee, Y.; Lee, S.; Lee, D.; Oh, T.K.; Sung, J. Metabolite profiling and mineral nutrient analysis from the leaves and roots of bell pepper (Capsicum annuum L. var. angulosum) grown under macronutrient mineral deficiency. Appl. Biol. Chem. 2018, 61, 661-671. [CrossRef]

67. Marschner, H. Marschner's Mineral Nutrition of Higher Plants; Academic Press: Cambridge, MA, USA, $2011 ;$ p. 672.

68. Morard, P.; Lacoste, L.; Silvestre, J. Effect of oxygen deficiency on uptake of water and mineral nutrients by tomato plants in soilless culture. J. Plant Nutr. 2000, 23, 1063-1078. [CrossRef]

69. Clarkson, D.T.; Lüttge, U. Mineral Nutrition: Inducible and Repressible Nutrient Transport Systems. In Progress in Botany; Springer: Berlin/Heidelberg, Germany, 1991; Volume 52, pp. 61-83.

70. Kramer, P.J.; Boyer, J.S. Water Relations of Plants and Soils; Academic Press Inc.: San Diego, CA, USA, $1995 ;$ p. 512. 